\title{
"Visible" at Last? Some Notes on English as a Target Language and Translated Books in the US
}

\begin{abstract}
In the international system of translations, English has been described as playing a "hypercentral" role. At the same time, translation is seen as playing a marginal role in the AngloAmerican cultural and publishing scenarios. The present paper is aimed at revisiting this idea. After an overview of recent studies that have examined the role and significance of translated titles in the publishing markets of English-speaking countries, the paper reports on an exploratory analysis of records available in a database that collects information on books in translation published or distributed in the US starting from 2008. The analysis indicates that translation is enjoying a renewed attention in the US market, in terms of both the number of translated titles and the distribution of translations across different genres.
\end{abstract}

Keywords: translated books, translation flows, globalization, translation into English, translated literature

\section{Končno "vidni”? Angleščina kot ciljni jezik in prevedene knjige $\mathbf{Z}$ ZDA}

\section{IZVLEČEK}

$\mathrm{V}$ mednarodnem prevodnem sistemu velja, da angleščina zavzema "hipersrediščni« položaj, prevajanje $\mathrm{v}$ kontekstu anglo-ameriške kulture in založništva pa obrobnega. Pričujoči prispevek je posvečen ponovnemu premisleku o tej ideji. Po pregledu novejših raziskav, ki so razčlenile vlogo in pomen prevodov na založniških trgih angleško govorečih držav, je v članku predstavljena analiza baze podatkov, $v$ kateri se zbirajo informacije o prevedenih knjigah, ki se izdajajo ali distribuirajo v ZDA od leta 2008 dalje. Analiza kaže, da je prevajanje znova deležno večje pozornosti tudi na ameriškem trgu, tako kar zadeva število prevodov, kot tudi žanrov, ki se prevajajo.

Ključne besede: prevedene knjige, prevodni tokovi, globalizacija, prevajanje v angleščino, prevodna književnost 


\section{Introduction}

The role of English with respect to translation has recently received renewed attention on the part of scholars. Not only in translation studies, but also in areas such as linguistics, literary studies, cultural sociology and publishing, both scholars and commentators have felt the need to reappraise the ways in which English, seen as the dominant language of international communication, affects the dynamics of translation markets and, more generally, of language and cultural contact.

In this article I propose an overview of studies which in recent years have looked at the role of English in the international system of translations and, more specifically, at the role and significance of translated titles in the publishing markets of English-speaking countries. My immediate aim is to check whether the traditional view of English as primarily a source language in the publishing industry is still justified. Statistical data about the number of translated titles that are published and sold in English-speaking countries would seem to support this view, but their reliability has been put into question (Pym and Chrupała 2005, 31-32; Zhou and Sun 2017, 115-16). At the same time, quite a few scholars and observers have pointed to an increased attention and a change of attitude towards translated literature in the media. This may have been helped on the one hand by the new modes of distribution of published titles (in terms of formats, such as e-books and audio books, and online commercial platforms) and, on the other, by the increased tendency to rely on the interaction between media formats to promote best-selling authors, who are effectively turned into franchises responsible for books but also films and, increasingly, TV series based on or inspired by their books.

The studies included in the present overview are concerned with issues related to the following questions: is it true that the number of books in translation sold in English-speaking markets is still very limited compared to other markets? Considering the books that are translated into English, is it possible to detect patterns in terms of source languages, countries of origin and genres? If, regardless of changes in sales, a renewed attention to translated titles by critics and the media can be assumed, what is it that led to this change? How do literary works cross borders in general, and what factors play a predominant role when the literary bordercrossing occurs from the "periphery" to the "core" of the global publishing market? What are the linguistic and stylistic features of translated literature in English? My intention is not that of providing extensive and definitive answers to these questions. Rather, I'd like to sketch out a few ideas and try to link them to new approaches that relate translation to the dynamics of the global circulation of goods and commodities, including cultural and intellectual products. I am interested, in other words, to learn more about the ways in which investigating translation into English, i.e., the dominant, "hyper-central" (Heilbron 2000) language of the global publishing market, can contribute to delineating "the disciplinary changes that a global focus brings to translation studies" (Bielsa 2020, 3). These changes have to do both with the emergence of new topics for research and the adoption of new methodological perspectives and paradigms, especially ones that are better suited to account for the at times extreme language diversity associated with today's global exchanges.

One overarching idea for the questions explored in my discussion is that of "translation flows", as initially characterized by Heilbron (1999). These flows can be observed in essentially 
quantitative terms (i.e., how many books are translated between any given pair of languages), but hypotheses can also be put forward, with reference to a variety of factors, as to what produces or conditions these flows. These factors may have to do, for instance, with the relative prestige of the languages and cultures involved, the role of individuals (e.g., translators or literary agents), policy decisions, or business or marketing strategies. One notion that should never be left aside when observing and analysing translation flows is that books are today mainly traded as a "cultural commodity" (Thompson 2010). In my overview, I'll refer to some recent studies or reports that have attempted to provide an up-to-date quantitative picture of such flows, especially in relation to books translated into English. For reasons I'll mention during the discussion, obtaining reliable data on book sales in any market is not a straightforward matter, and translated books are no exception. Various studies have used data from UNESCO's Index Translationum, ${ }^{1}$ but these are only available up to 2009. A report specifically dedicated to the percentage of translated books in the UK and Irish markets (Büchler and Trentacosti 2015) examines the years between 1990 and 2012. While no such report is available for the US market, data on translated books in the US starting from 2008 are available in the Three Percent translation database hosted by the Publishers Weekly website. In the final section of the article, I present, as a case study, an exploratory analysis of these data, in counterpoint to the findings presented by Büchler and Trentacosti (2015) for the UK and Irish markets.

For clarity of exposition I will divide my overview of existing studies into three short subsections, based on the predominant disciplinary interest or focus of the studies I give an account of, or - in other words - on the types and nature of the factor(s) elucidated by each study. This division by no means implies that either the studies or the questions they address should be seen as unrelated or even mutually irrelevant. In fact, the phenomena they investigate may be seen to overlap to a considerable degree. As frequently happens when translation, translations or translators are investigated, an interdisciplinary perspective is the one best suited to explore the issues at hand and to analyse the interrelation between the different factors involved. My account of the three, interconnected disciplinary "views" on translation into English will obviously be very personal and selective and it is likely to require integrations from other disciplinary standpoints, for example that of "world literature", which could be taken as an additional, independent perspective on the role of translation in the international circulation of literary works. The case study on translated books in the US presented in Section 3 of the article is mainly intended as an exploratory investigation, and one likely to suggest avenues for further, more rigorous analysis in either statistical or qualitative terms.

\section{Disciplinary Perspectives on Translation into English}

\subsection{The View from Translation Studies}

From a translation studies perspective, Laviosa $(2018,449)$ assesses "the world status of English in terms of its central role in the international translation system". She explicitly acknowledges

At the time of writing, the web page for accessing the Index Translationum within UNESCO's website is under maintenance. Therefore, no URL can be specified for it. 
that one of the main concerns of translation studies is the study of the translation procedures "that perpetuate this alleged one-way flow of culture, by effacing the cultural values of other languages in English translations and encoding English cultural values in texts translated into other languages". In particular, when English is the target language, its hegemonic status leads to the use of textual translation procedures that depend on "domestic cultural values" (Laviosa 2018, 450). This observation is in line with the fundamental argument proposed by Venuti (2008), according to which literary texts translated into English in the US systematically adopt a domesticating approach that is ultimately aimed at rendering the translator "invisible" and establishing relations with works in the same genre originally published in English. The same underlying strategy, notes Laviosa, can be observed in the "shallow multilingualism" of recent transnational authors writing in English, as studied in particular by Pandey (2016): the multilingual elements in these writers' works are ultimately intended to create a familiarizing effect, which is in stark contrast to the alienating effect sought by most transnational authors who published in English in the 20th century. The multilingual elements in more recent transnational writers are token and cosmetic, and they are used in the service of normative monolingualism.

The effects or consequences of the role of English as the dominant language in the global market of translations are also discussed by MacKenzie (2018) as part of a sociolinguistic overview of the position of English in the world and the ways in which it is affected by, and affects, other languages through language contact. Following remarks by Parks (2015), Mackenzie (2018, 130) notes, in particular, the increase in the number of writers, and especially novelists, who "deliberately simplify their style and eschew local cultural references to facilitate translation into English as a gateway to the global market". He also adds (Mackenzie 2018, 143), however, that not all authors who have enjoyed critical or commercial success in translation into English fit this description.

A more nuanced view of the translatability assumingly inherent in the work of writers who have enjoyed international success is offered in two studies by Segnini $(2017 ; 2018)$ who focuses on the Italian authors Elena Ferrante and Andrea Camilleri. In particular, Segnini points out the ambivalence of the cultural specificity represented by these authors. On the one hand, the choice of authors to be presented in translation is based on a process of selection in which "preference is given to translation-friendly texts, works that radiate vernacular flavour but do not challenge the knowledge or expectations of target audiences" (Segnini 2017, 115). On the other, the appeal of authors such as Ferrante and Camilleri can be related to international readers' needs for authenticity as a dimension of the local. As a result, their success can be seen to emerge from the interplay between resistance and adherence to the mechanisms of the global market.

\subsection{The View from Cultural Sociology}

The idea of treating translated literature as part of a larger literary "polysystem" was first proposed by Even-Zohar (1978). Later, Heilbron (1999) proposed a sociological framework presenting the translation of books as a "cultural world-system". In essence, this system is described in terms of a core-periphery structure which accounts for the uneven flow of 
translations between languages and for the varying role of translations within each language community or country. In this model, core position (or centrality) is the result not so much of the number of native speakers of a language as of the number of speakers for whom that language is a second language and the share of books translated from that language.

The core-periphery model has been expanded and refined in later studies by both Heilbron and Gisele Sapiro, writing together or independently (see, for instance, Heilbron 2000; Heilbron and Sapiro 2018). A useful overview of the questions and topics related to translation flows as analysed by studies adopting a cultural-sociological perspective is provided by Sapiro (2016) herself. The questions these models investigate have to do with how literary works circulate beyond national borders and what obstacles they encounter. Sapiro identifies four main categories of factors (political, economic, cultural, and social), with the usual proviso that in reality they may be intertwined. The political (or, more broadly, ideological) factors are those relating to the situations in which translation serves as a means to disseminate a particular doctrine or vision of the world. In some cases, this objective of dissemination may function obliquely, such as when translation is used to circumvent censorship. In a perspective of power relations between countries, translation may become an object of ideological and cultural exportation, with governments allocating financial support for the translation of books into one or more specific foreign languages.

The economic factors affecting the circulation of literary works are related to the book and press industries and to distribution networks. As far as the US and the UK are concerned, Sapiro $(2016,87)$ points out that in these two countries, "cultural goods appear primarily as commercial products that must obey the law of profitability". In the US and UK, the concentration of book production (reinforced by the concentration of book distribution around chains) turns translation into an unattractive commercial option, which ultimately ends up having a negative impact on cultural diversity. The publication of books in translation, in other words, is considered unprofitable, even though the pole of small-scale production (i.e., small independent publishers) has traditionally been able to ensure a minimum quota of diversity in the presentation of international literature to an English-speaking audience.

The cultural factors in the international dissemination of literary works as identified by Sapiro can be related to two main aspects. One is the contribution of translated works to the formation of national literary canons, a role that has more recently been discussed in relation to the canon of "world literature", defined as "all literary works that circulate beyond their culture of origin, either in translation or in the original" (Damrosch 2003, 4). The other aspect of relevance in terms of cultural factors is the role of translation in securing "symbolic profits" (such as recognition in the literary field) to those who promote it, e.g., translators, publishers, and critics. From this perspective, which draws on the works of Pierre Bourdieu, translation responds to the specific logic of "cultural fields" and is not subject to political and economic constraints.

Finally, the social factors Sapiro relates to the international circulation of literary works concern the power relations between different social groups and the ways in which these shape literary canons and redirect interest towards authors coming from groups that were previously marginalized (e.g., postcolonial writers and female authors). 
Of particular relevance with respect to translation into English, is Sapiro's (2016) description of the structure of the global book market. This is illustrated in more detail in a previous study (Sapiro 2010, 421), where the publishing market is said to combine "high concentration" with "great dispersal" and to be articulated around three levels: "production" (with conglomerates in competition with small independent publishers), "spatial relations" (in terms of core vs periphery), and "circulation" (which can be large-scale or small-scale). Based on this description, it can be added that the translation of books into English seems to have been affected by developments on all these three levels. In terms of production, conglomerates now have to face direct competition from other conglomerates which are not strictly speaking publishers, such as Amazon. Spatial relations have also been redefined by e-commerce and new modes of distribution such as e-books. Finally, circulation has changed, once again thanks to new modes of distribution: even a few copies of a given book can today be circulated on request, or "print on demand".

\subsection{The View from Publishing and Bibliometrics}

What is translated (which particular titles, authors and genres) and where translations are "produced" (i.e., written, printed and distributed) and by whom (i.e., by what publishers) have traditionally been among the objects of "translation history" (see the overview in D'hulst 2010). More recently, translation history has "turned its attention to the networks of agents involved, the technologies with which translations are produced, and their reception and impact" (O'Sullivan 2012, 131). The adoption of empirical approaches, including corpusbased research and the collection of quantitative and visualizable data, was already advocated in one of the seminal works in this area, i.e., Anthony Pym's (2014) Method in Translation History, originally published in 1998. A recent overview of the various bibliographical sources available for quantitative research in translation history is provided in Zhou and Sun (2017), who focus on sources comprising metadata and allowing the batch retrieval of records (as opposed to sources where data can only be "handpicked", such as online bookstores). These sources include catalogues of various kinds and "subject bibliographies". The catalogues may be those available in national libraries, "union catalogues" that combine library catalogues of a group of participating libraries, or trade catalogues (such as Bowker's Books in Print). ${ }^{2}$ Of the "subject bibliographies" devoted to translated books the most well-known is UNESCO's Index Translationum, which in the digital, online version contains bibliographical information on books translated and published in about one hundred of the UNESCO Member States between 1979 and 2009, for a total of over two million entries in all disciplines.

Some problems associated with using data contained in bibliographical databases for quantitative analyses of translation flows are discussed in Poupaud, Pym, and Torres Simón (2009). These problems have to do with aspects such as possible inconsistencies in the census techniques, leading to marked fluctuations in year-on-year data, and a lack of agreement on basic categories such as "books" or "translations", especially in databases that combine information coming from different countries. Still, the authors note, by appropriately defining the specific object of their research and by accepting that results from a given database are

See https://about.proquest.com/products-services/print-books/Books-in-Print.html. 
supplemented with information from other relevant sources, interesting findings can be obtained that shed light on the significance of particular translation flows. ${ }^{3}$

\section{Book Translations into and from English: Recent Trends}

Using data from UNESCO's Index Translationum, Zhou and Sun (2017) show that in recent decades English has been the most translated language in the world. In particular, between 1979 and 2007 the proportion of translated books with English as the original language increased from $40 \%$ to around $60 \%$ worldwide. In absolute terms, the annual number of books translated from English went from slightly over 20,000 in 1979 to around 67,000 in 2007. After English, the other top four source languages for translated books over the period 1979-2007 were French, German and Russian. The first two exhibited a steady increase year after year, while still remaining very distant from English: both started with around 5,000 translations in 1979 and went up to around 10,000 in 2007. Russian ranked second in 1979 but declined markedly after 1991, the year the Soviet Union collapsed. These, or similar figures found in other studies, are often used as the basis for the claims about the predominance of English as a source language in international translation flows. In the same paper, Zhou and Sun also present the list of the top five target languages worldwide in the same time span (1979-2007): German, French, Spanish, English and Japanese. As can be seen, English ranks fourth in the list. ${ }^{4}$

"Three percent" is the oft-quoted share of translations (especially literary) in the publishing output of the UK and US. Sapiro $(2010 ; 2016)$ accepts this estimate and takes it as a sign that the concentration on large scale production in the book industry has had a negative impact on cultural diversity at global level. An overview of the market of translated books in the US is provided by Ban (2015), who enumerates and discusses the difficulties (real or perceived) of publishing titles in translation on the North American market. These difficulties have to do with both editorial and financial aspects. From the editorial angle, one particular difficulty is related to the inability of many editors to read foreign languages, which is felt by many as an obstacle for a full appreciation, and the accurate editing, of a translated title. Not all editors consulted by Ban, however, agree that this is a major problem, and some even maintain that consulting the original may be distracting. More generally, some of the industry actors consulted by Ban $(2015,164-65)$ mention problems linked to the evaluation of translations, and especially their quality relative to the original text, although some publishers or editors point out that problematic manuscripts may also come from English-speaking authors.

From the financial perspective, the difficulties Ban discusses are related to the cost of translations, the acquisition of rights and the promotion of translated titles. That a translation is more expensive than an original manuscript is not always and necessarily true. If the price

For instance, if someone is interested in investigating all the "published" translations of a given author in one particular language, they may have to combine data from a commercial database produced by the publishing industry (which is likely to focus on translated titles that are distributed for sale) and data from other sources that include translations published for non-commercial use.

A more recent contribution (Brisset and Colón Rodríguez 2020) analysing data from the Index Translationum confirms the findings of Zhou and Sun (2017) with respect to the position of English as both a source and target language. 
of rights is considered, then translating a book may even turn out to be less expensive than acquiring an original manuscript (Ban 2015, 166). Another way to profit from translation is to acquire the world rights for a title and then sell rights of translation to other countries (Ban 2015, 167). In terms of marketing and promotion, although some publishers consider translated titles to be at a disadvantage due to lacking a "platform" (i.e., blogs or author friends who write blurbs or recommend books through social media or at their universities), others point out that communities of readers are forming around translated books, promoted at times by smaller, specialized publishers. Some publishers, such as Europa Editions, have even pursued "brand identification" (Ban 2015, 167) through their book covers.

At the end of her overview, Ban $(2015,172)$ lists some of the signs that the US publishing industry is paying increased attention to foreign titles: these include the creation of an exclusive area for books in translation and translation grants at Book Expo America (the main publishing event in the country), websites that facilitate the negotiation of foreign rights, and newsletters, blogs and literary magazines presenting international fiction in English. US media in general have, according to Ban, started to change their attitude towards translated literature (and here it is worth noting that Ban's article was written immediately prior to the international commercial and critical sensation caused by Elena Ferrante's novels).

For the UK and Irish publishing markets, a statistical report on the number and percentage shares of translated titles is presented in Büchler and Trentacosti (2015). The report uses data from the British National Bibliography (as received from the British Library) for the period 1990-2012. More specifically, raw data from the British Library were used by the authors to calculate the percentage shares of translations published annually, while refined data (restricted to translations of creative literary genres) were used for the analysis of translated titles according to source languages and genres. The report found that the translations published in the United Kingdom and Ireland in the analysed period represented around $3 \%$ of all publications and that literary translations account for around $4 \%$ of all literary publications, with a peak in 2011, when translations surpassed 5\% (in the report, "literary" refers to titles falling within the 800 Dewey classification category).

\subsection{Translated Books in the US in Recent Decades}

In their report, Büchler and Trentacosti $(2015,6)$ acknowledge that for the creation of their database they were inspired partly by the annual book market reports of EU countries (usually also containing translation statistics), and partly by the Three Percent project in the US. Three Percent is a website 5 launched and maintained by Rochester University and Open Letter, its translation press, with the goal of becoming "a destination for readers, editors, and translators interested in finding out about modern and contemporary international literature". The website contains reviews of books in translation, articles on translation-related matters and a translation database collecting raw data on translated books published and distributed in the US. Since 2019 the Three Percent database has also been available on the website of Publishers Weekly ${ }^{6}$ in a searchable format and with an enlarged focus: while initially the database only

See http://www.rochester.edu/college/translation/threepercent/.

See https://www.publishersweekly.com/pw/translation/home/index.html. 
collected information on translated fiction and poetry, in its current version it also includes data on children's books and non-fiction titles. The time span covered by the database is 2008 to the present. Entries in the database are mainly added by hand based on publishers' catalogues and review copies. Individual authors, translators, publicists and readers can also add entries through a dedicated online form. The database can be searched using a number of criteria, including title, genre, ${ }^{7}$ name and gender of author, name and gender of translator, author's country of origin, year of publication, publisher, and more. Records from the database can be imported in tab-delimited format into a spreadsheet for statistical analysis. ${ }^{8}$ In what follows I will propose a brief exploratory analysis of the data available in the Three Percent database, in the attempt to uncover some general trends and discuss them with reference to the data about the UK and Irish markets (as presented in Büchler and Trentacosti 2015) and against the background of sales figures in the US publishing markets for recent years. The time span for the data presented here is 2008-2020. The analysis refers to the contents of the database as of February 2021.

For the years between 2008 and 2020, the Three Percent database contains records for a total of 8,443 titles. Table 1 shows the number of translated titles per year for all four macro-genres covered by the database. There is a steady and marked increase in the number of recorded titles, with two peaks, one in 2013 (the highest number of titles in the time span considered) and one in 2018. Although the numbers decline after 2018, they still remain considerably higher than in 2008. For 2020 the number of titles is 531, with an increase of $39 \%$ over 2008, the year with the lowest figure in the time considered.

Table I. Number of translated titles in the US in the period 2008-2020 according to the Three Percent data.

\begin{tabular}{|c|c|c|c|c|c|c|c|c|c|c|c|c|}
\hline 2008 & 2009 & 2010 & 2011 & 2012 & 2013 & 2014 & 2015 & 2016 & 2017 & 2018 & 2019 & 2020 \\
\hline 386 & 389 & 372 & 429 & 844 & 936 & 843 & 669 & 720 & 776 & 810 & 737 & 531 \\
\hline
\end{tabular}

Figure 1 provides a different view of the same data that better highlights the overall increasing trend in the number of translated titles, showing in particular that for a period of five years (i.e., from 2012 to 2019) the number of translated books consistently remained above the threshold of 600 titles.

To put these numbers in perspective, consider that the UK and Irish markets (Büchler and Trentacosti 2015) saw a steady increase in the number of published literary translations from 2000 to 2012, with a peak of 587 in 2011 . As a percentage of all published literary titles, in the UK and Irish markets translated titles did indeed oscillate between $4 \%$ and $5 \%$ for most of the longer period (i.e., 1990 to 2012) considered by Büchler and Trentacosti (2015). The 2011 peak meant that translations reached 5.23\% of all published titles. A comparable proportional representation of the Three Percent data presented here would have to be made against national yearly data on published books in the US. Obtaining these, however, is not a straightforward matter, and once they had been obtained, the data would still require

The four macro-genres represented in the database are: fiction, non-fiction, poetry, and children's books.

See the FAQs about the database at https://www.publishersweekly.com/pw/corp/translation-database-FAQ.html. 


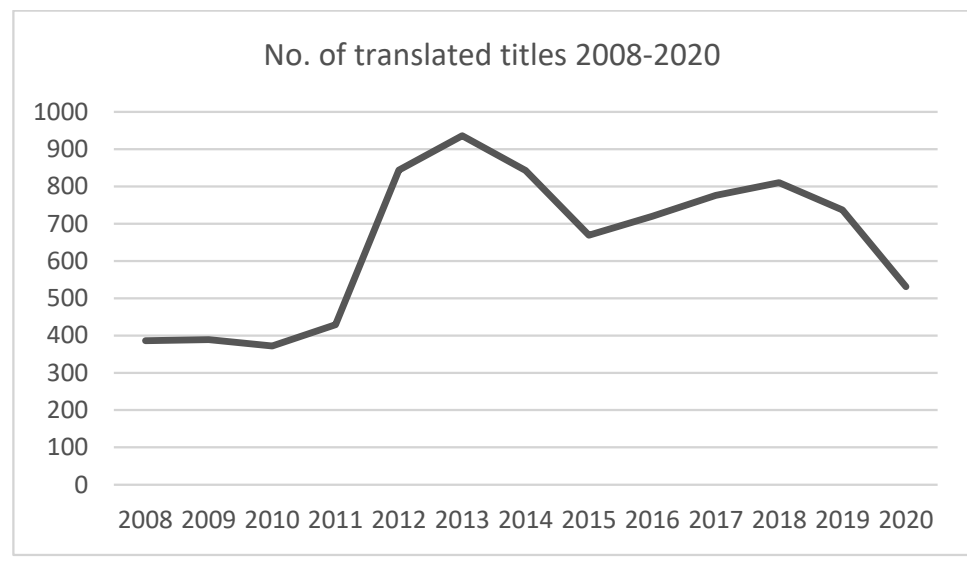

FIgURE I. Number of translated titles in the US in the period 2008-2020.

much more time for processing than was feasible for the present exploratory analysis. Even so, the trend visible in the Three Percent data seems to provide some support to the idea that, numerically, translated titles are on the rise in the US market.

Before focusing on figures on the most translated languages, it is worth giving a brief look at how the four macro-genres are distributed across all source languages. Table 2 provides an overview of the number of titles translated every year in each macro-genre. Fiction is by far the most translated genre (with $66.2 \%$ of all titles over the 12 -year period), followed a long way behind by poetry (14.8). Non-fiction follows closely behind poetry (12.8\%), and children's books come last at 6.2\%. In findings for the UK and Irish markets by Büchler and Trentacosti $(2015,18)$, fiction accounted for a similarly large share (i.e., around $60 \%)$ of translated titles.

TABLE 2. Distribution of translated titles in the US per macro-genre (2008-2020).

\begin{tabular}{|c|c|c|c|c|c|c|c|c|c|c|c|c|c|c|}
\hline Genre & $\begin{array}{l}\infty \\
\stackrel{8}{8} \\
\text { ㄱ. }\end{array}$ & ஓे & $\stackrel{0}{\circ}$ & 킁 & 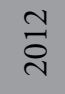 & $\frac{n}{8}$ & 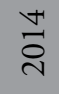 & $\frac{n}{i}$ & $\begin{array}{l}\text { } \\
\stackrel{\sim}{0}\end{array}$ & 홍 & $\stackrel{\infty}{\underset{\sim}{\sim}}$ & $\stackrel{\overbrace{}}{\text { ก }}$ & ్ㅗ & Total \\
\hline Fiction & 282 & 292 & 277 & 327 & 403 & 463 & 531 & 519 & 569 & 530 & 560 & 493 & 340 & $\begin{array}{c}5586 \\
(66.2 \%)\end{array}$ \\
\hline Poetry & 88 & 87 & 86 & 87 & 83 & 102 & 108 & 107 & 117 & 143 & 122 & 80 & 41 & $\begin{array}{c}1251 \\
(14.8 \%)\end{array}$ \\
\hline Nonfiction & 3 & 6 & 8 & 11 & 237 & 226 & 93 & 37 & 29 & 79 & 113 & 116 & 115 & $\begin{array}{c}1073 \\
(12.8 \%)\end{array}$ \\
\hline Children's & 13 & 4 & 1 & 4 & 121 & 145 & 111 & 6 & 5 & 23 & 14 & 48 & 35 & $\begin{array}{c}530 \\
(6.2 \%)\end{array}$ \\
\hline
\end{tabular}

Of particular interest, in Table 2, is the marked increase in the number of translations of non-fiction titles. Only 28 titles are recorded for this genre between 2008 and 2011, but there is a sudden, remarkable leap to 237 titles in 2012 (which is also the peak year of the period). In spite of some oscillations, the share of non-fiction titles remains significant over 
the subsequent years, and in some cases (e.g., 2012, 2013, 2019, and 2020) it is higher than the share of translated poetry titles. Poetry itself, on the other hand, sees a trend of significant growth between 20012 and 2018. A closer look at the source languages, individual authors and publishers for both the non-fiction and poetry titles might shed some light on these trends and contribute to explaining what is undoubtedly a sharp increase in the attention devoted to the translation of these genres.

Data on the most translated languages as available in the Three Percent database are given in Table 3, which focuses on the top 20 source languages for translated titles and indicates how many were translated from each language every year.

TABLE 3. Top 20 most translated languages in the US (2008-2020).

\begin{tabular}{|c|c|c|c|c|c|c|c|c|c|c|c|c|c|c|}
\hline & ஓ্ণ & ஓి & $\stackrel{\circ}{\stackrel{0}{8}}$ & 킁 & 궁 & ?) & ্ָণ & $\frac{n}{8}$ & 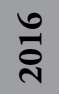 & 승 & $\stackrel{\infty}{\frac{\infty}{\text { స }}}$ & হి & ণ্ণి & Total \\
\hline French & 66 & 55 & 64 & 67 & 177 & 213 & 178 & 136 & 122 & 140 & 133 & 145 & 122 & 1618 \\
\hline Spanish & 52 & 67 & 54 & 54 & 91 & 106 & 95 & 86 & 113 & 107 & 124 & 100 & 80 & 1129 \\
\hline German & 32 & 37 & 38 & 46 & 147 & 140 & 146 & 85 & 85 & 76 & 73 & 73 & 58 & 1036 \\
\hline Italian & 14 & 26 & 21 & 24 & 69 & 64 & 51 & 42 & 35 & 41 & 47 & 46 & 37 & 517 \\
\hline Japanese & 21 & 19 & 27 & 26 & 41 & 44 & 30 & 21 & 30 & 48 & 64 & 47 & 32 & 450 \\
\hline Swedish & 19 & 17 & 10 & 21 & 30 & 33 & 37 & 23 & 33 & 33 & 29 & 29 & 23 & 337 \\
\hline Arabic & 30 & 21 & 17 & 18 & 28 & 23 & 30 & 27 & 27 & 32 & 24 & 22 & 11 & 310 \\
\hline Chinese & 15 & 9 & 14 & 16 & 26 & 22 & 31 & 24 & 25 & 39 & 32 & 27 & 20 & 300 \\
\hline Russian & 20 & 15 & 11 & 19 & 30 & 38 & 31 & 16 & 15 & 18 & 25 & 28 & 16 & 282 \\
\hline Norwegian & 6 & 11 & 8 & 14 & 14 & 20 & 18 & 15 & 20 & 28 & 28 & 20 & 16 & 218 \\
\hline Portuguese & 16 & 9 & 7 & 11 & 20 & 23 & 23 & 17 & 18 & 12 & 20 & 19 & 11 & 206 \\
\hline Dutch & 3 & 10 & 9 & 2 & 35 & 33 & 16 & 9 & 10 & 9 & 19 & 24 & 16 & 195 \\
\hline Hebrew & 12 & 6 & 14 & 12 & 12 & 24 & 9 & 13 & 17 & 15 & 13 & 14 & 15 & 176 \\
\hline Korean & 4 & 8 & 4 & 16 & 5 & 15 & 15 & 14 & 24 & 16 & 11 & 17 & 13 & 162 \\
\hline Danish & 3 & 3 & 3 & 11 & 11 & 14 & 14 & 17 & 12 & 16 & 15 & 14 & 3 & 136 \\
\hline Polish & 6 & 4 & 8 & 7 & 16 & 13 & 8 & 5 & 5 & 11 & 15 & 7 & 9 & 114 \\
\hline Czech & 5 & 7 & 5 & 4 & 4 & 6 & 7 & 8 & 12 & 16 & 8 & 3 & 2 & 87 \\
\hline Turkish & 4 & 12 & 3 & 3 & 6 & 11 & 5 & 8 & 10 & 6 & 5 & 4 & 3 & 80 \\
\hline Finnish & 2 & 2 & 2 & 2 & 5 & 8 & 7 & 11 & 11 & 10 & 6 & 7 & 4 & 77 \\
\hline Icelandic & 3 & 3 & 2 & 2 & 11 & 8 & 7 & 3 & 5 & 8 & 11 & 5 & 4 & 72 \\
\hline
\end{tabular}

A brief comparison and contrast of the languages in Table 3 with data on the most translated languages in the UK and Ireland from Büchler and Trentacosti (2015) provides some interesting insights. Even though the UK and Ireland figures refer only to the translations of literary texts, they can still be taken to be comparable with data from the Three Percent 
database, where fiction and poetry are the most represented genres (see Table 2). The comparison is particularly interesting as far as the top 10 languages are concerned (Table 4). ${ }^{9}$

TABLE 4. Top 10 most translated languages in the US (2008-2020) and in the UK and Ireland (2000-2012).

\begin{tabular}{|l|c|l|c|}
\hline \multicolumn{2}{|l|}{ US } & \multicolumn{2}{l|}{ UK-Ireland } \\
\hline Language & No. of titles & Language & No. of titles \\
\hline French & 1,618 & French & 1,217 \\
\hline Spanish & 1,129 & German & 728 \\
\hline German & 1,036 & Spanish & 481 \\
\hline Italian & 517 & Russian & 432 \\
\hline Japanese & 450 & Italian & 383 \\
\hline Swedish & 337 & Swedish & 359 \\
\hline Arabic & 310 & Norwegian & 190 \\
\hline Chinese & 300 & Dutch & 185 \\
\hline Russian & 282 & Arabic & 135 \\
\hline Norwegian & 218 & Japanese & 123 \\
\hline
\end{tabular}

In the US top 10 list, the non-European languages feature more prominently. Japanese ranks 5 th, (with a number of titles which is slightly lower than one third of the number for French, the most translated language); Arabic and Chinese rank 7th and 8th, respectively. By contrast, in the UK and Ireland top 10 list, the only two non-European languages are Arabic (9th) and Japanese (10th). The top three languages are the same in the two lists, with French ranking at number one in both. Spanish and German swap second and third places, with Spanish ranking second in the US. This could be a sign of the closer relationship of US publishers with the Spanish-speaking book markets in Central and South America. Country-of-origin data confirm this: of the 1129 titles translated from Spanish in the US, the vast majority (i.e., around 800) originate from Spanish-speaking Latin American countries.

Of particular interest in both lists in Table 3 is the presence of Swedish and Norwegian. The consistent and steady growth of translations from Swedish had already been noted (and labelled as "one of the most significant trends") by Büchler and Trentacosti $(2015,16)$. In their data, Norwegian showed a similar trend, with a peak of translated titles in the same year as Swedish (i.e., 2011). In the US data, if the analysis is extended to the top 20 translated languages (see Table 3), all of the Nordic languages feature very prominently. The interest in titles from these languages seems to emerge slightly later than in UK and Ireland, but from 2011 onwards it establishes a significant and consolidated trend: Swedish peaks at 37 translated titles in 2014, and remains at around 30 titles per year between 2012 and 2019. Norwegian also sees a steady increase from 2008, reaching a peak number of titles for two consecutive years (2017 and 2018). If taken collectively, the contingent of Nordic languages (Swedish, Norwegian, Danish, Finnish, and Icelandic, representing a population of around 27 million people) would rank, with a total of 840 translated titles, before Italian, a language representing a country with more than double the population. The case of Iceland

\footnotetext{
For the UK and Ireland, Table 3 collates figures from different tables in Büchler and Trentacosti (2015).
} 
and Icelandic is particularly impressive: from 2008 to 2020 a country of around 360,000 people had 72 books translated into English and published in the US - that is, only eight titles fewer than Turkey (population: 84 million). The attention to titles translated from Nordic languages can be linked to the critical and commercial success enjoyed by authors from Nordic countries, and especially writers of genre fiction such as thrillers and mysteries (e.g., Karin Fossum Anne Holt, Jo Nesbo, and Karin Fossum from Norway; and Camilla Lackberg, Stig Larsson, and Henning Mankell from Sweden).

The analysis of the Three Percent data could go on to uncover other trends and reveal interesting comparisons (and contrasts) with data on translation flows for other countries. The analysis could focus, for example, on individual countries and look at how the success of specific authors then contributed to drawing attention to other titles written in the same original language. Italy is a case in point. Data from the Three Percent database could, for example, help understand if and how the "Ferrante fever" (a journalistic label which later even became the title of a documentary film featuring an interview with Ann Goldstein, the translator of most of Elena Ferrante's novels into English) led to an increased number of similar titles translated from Italian into English. The data could also be used to test hypotheses about translation flows between the US and other non-European countries, building on the observation already made above that, in comparison to the other large English-speaking market (the UK), the US sees a much more significant presence of titles coming from outside Europe.

Complements to the analysis of the Three Percent data could (or indeed, in some cases, should) also be sought in data on book sales. A cursory look at some easily obtained data would seem to confirm that over the last decade or so translated titles have gained more visibility in terms of both critical acclaim and commercial success. According to the market research group NPD, The Girl with The Dragon Tattoo by the Swedish author Stig Larsson ranks number nine (with 7.9 million copies) in the list of the best-selling print books and e-books in the US in the period 2010-2019. ${ }^{10}$ The same report by NPD also highlights a growth in US sales of poetry titles and non-fiction titles in general in the latter half of the decade. This could be linked to the trends observed above (in Table 2) with regard the genre distribution of translated titles, with poetry and especially non-fiction showing marked increases in the number of published titles starting from 2011. More specifically, this could indicate that publishers are willing to invest in titles in translation in genres that enjoy commercial success.

\section{Final Remarks}

Several scholars and observers have agreed that the role and share of translations in Englishspeaking book markets are particularly weak if compared to those seen in markets such as France, Germany and Italy. Data from UNESCO's Index Translationum have often been used to back up claims on the extremely marginal role of translations in markets such as the US or UK, but these data are not available for the years beyond 2009. In this contribution, I have referred to a report based on more recent data (Büchler and Trentacosti 2015) showing that in the UK and Ireland the share of translations has in some years risen over the traditionally quoted threshold of "three percent". I have also proposed an exploratory analysis of the records

10 See the press release at https:/www.npd.com/wps/portal/npd/us/news/press-releases/2019/fifty-shades-of-grey-wasthe-best-selling-book-of-the-decade-in-the-us-the-npd-group-says/. 
contained in the Three Percent database, which collects information about titles published in translation in the US starting from 2008. Although the data from this resource have not been analysed against the background of the total publishing output of the United States, the analysis has pointed to a renewed vitality of books in translation, which has been linked to signs testifying to their critical and, in some cases, commercial success, as in the case of Elena Ferrante's novels or Scandinavian crime fiction.

In short, even in publishing markets that were traditionally considered particularly insular and self-referential, such as the UK and the US, books in translation have made it to the best-selling lists, and the presence of foreign authors in the culture sections of newspaper and magazines is no longer an exception. There are several signs that translations and translators are no longer as "invisible" at they were taken to be in the 1990s, when Lawrence Venuti first published his widely quoted The Translator's Invisibility (Venuti 2008).

Further investigation, and more rigorous quantitative analyses, would be needed to back up these claims and establish how consolidated the trends indicating a renewed vitality for translations into English really are. For the interpretation of these trends, support could also be sought in recent accounts of the ways in which cosmopolitanism and globalization are shaping translation in diverse social contexts and through the effect of supranational factors (see, in particular, the discussion of cosmopolitanism in Bielsa (2016) and the reflections on globalization and translation in Bielsa and Kapsaskis (2020)).

Claiming that translation is affected by supranational factors would appear to be a truism, as translation entails a supranational dimension by definition. However, approaches to translation and research paradigms up until, and including, Descriptive Translation Studies, rarely explicitly considered and investigated the flow of ideas and the dynamics of communication at supra- and transnational levels, preferring instead to concentrate either on the source or on the target poles of translational phenomena. One particular supranational factor that may be playing a role in the renewed interest in translation in English-speaking countries is the disembodied nature of much communication, i.e., the fact that it is not realized through spatial movements of people and products across borders, but rather through the exchange of ideas and content over digital networks. This may be having the effect of making readers (and film and TV viewers) in English-speaking markets more alert to cultural products coming from non-English speaking countries, in a process that global publishing (and film production) conglomerates may view favourably if it leads to increased sales and profits.

\section{References}

Ban, Ana. 2015. “Books in Translation in the United States." Publishing Research Quarterly 31 (3): 160-74. https://doi.org/10.1007/s12109-015-9406-7.

Bielsa, Esperança. 2016. Cosmopolitanism and Translation: Investigations into the Experience of the Foreign. Translation Theories Explored. London: Routledge.

Bielsa, Esperança. 2020. "Introduction: the Intersection between Translation and Globalization.” In The Routledge Handbook of Translation and Globalization, edited by Esperança Bielsa and Dionysios Kapsaskis, 1-10. London: Routledge.

Bielsa, Esperança, and Dionysios Kapsaskis, eds. 2020. The Routledge Handbook of Translation and Globalization. London: Routledge. 
Brisset, Annie, and Raúl E. Colón Rodríguez. 2020. "World Translation Flows." In The Routledge Handbook of Translation and Globalization, edited by Esperança Bielsa and Dionysios Kapsaskis, 230-50. London: Routledge.

Büchler, Alexandra, and Giulia Trentacosti. 2015. Publishing Translated Literature in the United Kingdom and Ireland 1990-2012. Statistical Report. Aberystwyth: Mercator Institute for Media, Languages and Culture, Aberystwyth University.

Damrosch, David. 2003. What Is World Literature? Princeton: Princeton University Press.

D’hulst, Lieven. 2010. “Translation History." In Handbook of Translation Studies, edited by Yves Gambier and Luc van Doorslaer, 1: 397-405. Amsterdam: John Benjamins. https://doi.org/10.1075/hts.1.tra5.

Even-Zohar, Itamar. 1978. “The Position of Translated Literature within the Literary Polysystem.” In Literature and Translation: New Perspectives in Literary Studies, edited by James S. Holmes, José Lambert, and Raymond van den Broeck, 117-27. Leuven: Acco.

Heilbron, Johan. 1999. "Towards a Sociology of Translation: Book Translations as a Cultural World-System.” European Journal of Social Theory 2 (4): 429-44. https://doi.org/10.1177 /136843199002004002.

—. 2000. “Translation as a Cultural World System." Perspectives 8 (1): 9-26. https://doi.org/10.1080 10907676X.2000.9961369.

Heilbron, Johan, and Gisèle Sapiro. 2018. "Politics of Translation: How States Shape Cultural Transfers." In Literary Translation and Cultural Mediators in 'Peripheral' Cultures, edited by Diana Roig-Sanz and Reine Meylaerts, 183-208. Cham: Springer International. https://doi.org/10.1007/978-3-319-78114 $-3 \_7$.

Laviosa, Sara. 2018. "English and Translation.” In The Routledge Handbook of English Language Studies, edited by Philip Seargeant, Ann Hewings, and Stephen Pihlaja, 447-60. London: Routledge.

MacKenzie, Ian. 2018. Language Contact and the Future of English. Routledge Studies in Sociolinguistics 18. New York: Routledge.

O’Sullivan, Carol. 2012. “Introduction: Rethinking Methods in Translation History." Translation Studies 5 (2): 131-38. https://doi.org/10.1080/14781700.2012.663594.

Pandey, Anjali. 2016. Monolingualism and Linguistic Exhibitionism in Fiction. Houndmills: Palgrave Macmillan.

Parks, Tim. 2015. Where I'm Reading from: The Changing World of Books. New York Review Books Collections. New York: New York Review Books.

Poupaud, Sandra, Anthony Pym, and Ester Torres Simón. 2009. "Finding Translations. On the Use of Bibliographical Databases in Translation History." Meta: Journal Des Traducteurs / Meta: Translators' Journal 54 (2): 264-78. https://doi.org/10.7202/037680ar.

Pym, Anthony. 2014. Method in Translation History. London: Routledge.

Pym, Anthony, and Grzegorz Chrupała. 2005. "The Quantitative Analysis of Translation Flows in the Age of an International Language." In Less Translated Languages, edited by Albert Branchadell and Lovell Margaret West, 27-38. Amsterdam: John Benjamins. https://doi.org/10.1075/btl.58.03pym.

Sapiro, Gisèle. 2010. "Globalization and Cultural Diversity in the Book Market: The Case of Literary Translations in the US and in France." Poetics 38 (4): 419-39. https://doi.org/10.1016/j.poetic.2010 .05 .001 .

—. 2016. "How Do Literary Works Cross Borders (or Not)?" Journal of World Literature 1 (1): 81-96. https://doi.org/10.1163/24056480-00101009.

Segnini, Elisa. 2017. "Local Flavour vs Global Readerships: The Elena Ferrante Project and Translatability." The Italianist 37 (1): 100-118. https://doi.org/10.1080/02614340.2016.1273649.

—. 2018. "Andrea Camilleri's Montalbano and Elena Ferrante's L'amica geniale: The Afterlife of Two 'Glocal' Series.” The Translator: 1-17. https://doi.org/10.1080/13556509.2018.1502607.

Thompson, John B. 2010. Merchants of Culture: The Publishing Business in the Twenty-First Century. Cambridge: Polity.

Venuti, Lawrence. 2008. The Translator's Invisibility: A History of Translation. 2nd ed. London: Routledge. Zhou, Xiaoyan, and Sanjun Sun. 2017. "Bibliography-Based Quantitative Translation History." Perspectives 25 (1): 98-119. https://doi.org/10.1080/0907676X.2016.1177100. 